\title{
Estrutura de Propriedade e Controle, Governança Corporativa e o Alisamento de Resultados no Brasil
}

\author{
Ownership and Control Structures, Corporate Governance and Income Smoothing in Brazil
}

\section{Damiana Torres}

Mestre em Administração (UNIFACS)

Técnica Judiciária do Tribunal Superior do Trabalho.

Endereço: R. Dr. José Peroba, 251, Sala 601, Stiep

CEP: 41.770-235 - Salvador/Bahia - Brasil

E-mail: damianatorres@yahoo.com.br

Telefone: (71) 3273-8607

\section{Adriano Leal Bruni}

Doutor em Administração (USP)

Professor da Universidade Federal da Bahia

Endereço: Praça 13 de Maio, 06 - Piedade

CEP: 40.070-010 - Salvador/Bahia - Brasil

E-mail: albruni@ufba.br

Telefone: (71) 3283-7667

\section{Miguel Angel Rivera-Castro}

Mestre em Contabilidade (UFBA), Doutorando em Energia e Ambiente (UFBA)

Professor da Universidade Federal da Bahia

Endereço: Praça 13 de Maio, 06 - Piedade

CEP: 40.070-010 - Salvador/Bahia - Brasil

E-mail: marc@ufba.br

Telefone: (71) 3263-7568

\section{Antonio Lopo Martinez}

Doutora em Controladoria e Contabilidade (USP)

Professor da Fucape Business School

Endereço: Av. Fernando Ferrari, no 1358, Sala 19, Boa Vista

CEP 29075-505 - Vitória/ES - Brasil

E-mail: lopo@fucape.br

Telefone: (27) 4009-4444 


\title{
Resumo
}

Este artigo procura verificar a associação entre o alisamento de resultados e a estrutura de propriedade e controle, o nível de governança corporativa e a origem do capital. Usando uma amostra de empresas não financeiras com ações negociadas na Bolsa de Valores de São Paulo no final de 2007, efetivou-se uma análise de covariância, onde a variável dependente foi o índice de alisamento de Eckel, proxy empírica de smoothing. Os resultados indicaram que quanto mais concentrada for a estrutura de propriedade e controle maior a tendência a ocorrer alisamento de resultados. Os resultados são indicativos de que as firmas com estrutura de propriedade e controle mais concentradas podem estar promovendo um alisamento de resultados artificial, buscando resguardar interesses dos acionistas majoritários e controladores, mediante a alteração da percepção de riscos dos acionistas minoritários.

Palavras-chave: estrutura de propriedade e controle; governança corporativa; alisamento de resultados

\begin{abstract}
This article examines the association between the ownership and control structure, level of corporate governance and origin of capital (foreign or domestic) of Brazilian companies on their propensity to smooth income. Using a sample of nonfinancial firms with shares traded on the São Paulo Stock Exchange (Bovespa) at the end of 2007, we performed covariance analysis based on data from the preceding ten years, where the dependent variable was the index proposed by Eckel, an empirical proxy for smoothing. The results indicate that the more concentrated the shareholding and control structures of Brazilian firms are, both according to overall capital and voting capital, the more intensely they tend to smooth earnings to favor the interests of the majority shareholder. The results also show that this effect is less pronounced for firms with enhanced corporate governance levels and those with foreign capital.
\end{abstract}

Key words: ownership and control structures; corporate governance; income smoothing

\section{Introduction}

Earnings management can be defined as a set of actions by managers, materialized through accounting and operational decisions, so that the firm will attain a certain accounting result (McNichols, 2000). There are various types of earnings management, among them income smoothing. According to Beidleman (1973), income smoothing is the intentional dampening of the fluctuations of the earnings series. The managers of many firms engage in this practice, because earnings volatility is generally seen by creditors and investors as an indicator of risk.

The aim of this paper is to contribute to the accounting literature by studying the relationship between income smoothing and the ownership and control structure of firms, as well as the corporate governance and origin of the capital. According to Silveira (2004), Brazilian companies tend to have concentrated ownership and control. Therefore, agency problems in Brazil generally do not materialize as conflicts between shareholders and managers, but instead as disputes between minority and majority shareholders. The latter tend to use their nower in favor of their own interests. which are not alwavs alioned with those of 
the minority shareholders.

To soften the various conflicts due to this uneasy relationship, there has been a recent effort to establish mechanisms that favor good corporate governance practices in Brazil. For example, the São Paulo Stock Exchange (Bovespa) has set up separate trading segments for companies that meet enhanced corporate governance standards, prompting many companies to improve their governance.

Another important point for the imposition of stricter rules in the Brazilian capital market was the Sarbanes-Oxley Act. Although this law only applies to companies with securities traded in the United States, it has had a big influence even on Brazilian firms, especially those that have substantial foreign ownership or securities traded in the American market, such as ADRs. These companies face particular pressure to hew to the most important rules of SOX, seen as a way to maintain good corporate governance practices.

In this context, in this work we analyze whether there is a relationship between income smoothing and the ownership and control structure of Brazilian firms with shares listed on the Bovespa and also the influence of the level of corporate governance and origin of capital on smoothing practices.

In summary, this paper examines aspects such as the degree of smoothing by listed Brazilian firms, the level and impacts of ownership concentration of these firms, the importance of the information disclosed to the market, the influence of external regulations on Brazilian firms (such as the Sarbanes-Oxley Act on companies that access the American capital market through ADRs) and the impacts of corporate governance mechanisms on business practices.

These points demonstrate the relevance of the theme of income smoothing, because one of the most important products of accounting for users of information is the result (profit or loss), the main measure of firms' performance. In looking for correlations between income smoothing and the other variables cited, this work tries to predict some of the factors able to determine this accounting practice. Does the ownership and control structure really impose incentives to smooth earnings?

This article is divided into five sections including this introduction. The next section presents the theoretical framework and hypotheses, while the third section describes the database, models and statistical methods employed. The fourth section then presents and discusses the results and the fifth section contains the final considerations and briefly analyzes their implications.

\section{Theoretical Framework and Research Hypotheses}

Earnings management is not a new theme in Brazil. Martinez (2001), Tukamoto (2004) and Paulo (2007), among others, have investigated this subject 
and noted its growing importance, principally because of the various corporate accounting scandals around the world.

However, income smoothing and its relationship with ownership structure in Brazil have not attracted significant attention from researchers. In the international literature, authors such as Berle \& Means (1932), Jensen \& Meckling (1976), among others, have studied the ownership and control structure of companies in various countries. In Brazil, works such as Rapozo et al. (2007), Ribeiro et al. (2006), Okimura et al. (2004), Fontes Filho (2003) and Silveira (2004) have investigated the theme, relating it with other variables, and have noted that Brazilian firms for the large part have concentrated ownership and control structures.

The relationship between these two themes - ownership structure and income smoothing - has been studied by a number of international authors, like Chalayer (1994), Smith (1976), Amihud et al. (1983), Kamin \& Ronen (1978), Koch (1981) and Beattie et al. (1994). However, to the best of our knowledge, this is the first study to address this particular issue for the Brazilian market.

Besides this, in our literature review we also did not find any works examining the correlation of these two themes with variables such as corporate governance and origin of capital. The level of governance has been studied by Babic (2003) and Rogers et al. (2006), and Martinez \& Ramos (2006) sought to explain the relationship between these variables, but with different variables on ownership structure and proxies for earnings management than those used here.

With regard to the origin of capital, Okimura et al. (2004) investigated the influence of foreign or national capital on companies, but they did not examine the relationship between this variable and those analyzed in this work. Camazano \& Arima (2008) and Peçanha (2007) researched the influence of foreign legislation on Brazilian companies - especially the Sarbanes-Oxley Act - but did not address the relationship of this aspect with ownership structure and earnings management.

This work tests three complementary hypotheses:

(H1) In Brazil, firms with a more concentrated ownership and control structure smooth income more intensely;

(H2) The effect of ownership and control structure on income smoothing is smaller for firms with higher levels of corporate governance;

(H3) Companies with concentrated ownership and control structure that smooth income do so more intensely when they have a private national controller.

The first hypothesis follows the lead of international works such as those by Chalayer (1994), Smith (1976), Amihud et al. (1983) and Rajgopal et al. (2002), among others, which have found evidence that in the United States and Europe concentrated ownership can reduce the principal-agent problem between 
shareholders and managers, lowering the incentives and opportunities for the latter to manage earnings. However, we do not expect these relations between ownership and control structure and accounting information to apply to Brazilian firms due to the differences in the degree of shareholding concentration and the associated types of agency problems.

When the ownership and control structure is diffuse, as is typical in the United States, agency problems typically arise from the conflict between managers and shareholders. But with a more concentrated shareholding structure, the nature of the agency problem tends to shift to a conflict between the majority and minority shareholders (Sheifer \& Vishny, 1997). When a single shareholder gains effective control over a corporation, its decisions can result in appropriation of value from the minority stockholders.

When a single shareholder (or block of shareholders acting in concert) controls a firm, as is the pattern in Brazil, it also controls the accounting choices. In this context, the controlling shareholder has strong incentives to manage reported earnings to serve its own private interests instead of reflecting the true financial situation of the firm. Based on this, we expect that in Brazil as the ownership and control structure becomes more concentrated, there will be stronger incentives to engage in earnings management, and more specifically in income smoothing.

The second hypothesis suggests that firms with concentrated ownership structures that adhere to a stock listing segment that requires higher levels of corporate governance will smooth income less than firms with similarly concentrated structures that do not follow enhanced governance mechanisms. This statement seems intuitive because one of the points of better corporate governance is to assure more accurate and transparent information. Studies like those of Rogers et al. (2006) and Martinez \& Ramos (2006) have found evidence of this relationship.

Finally, the third hypothesis assumes that firms with concentrated ownership structures and significant foreign ownership will smooth income less than similarly concentrated firms without such foreign participation. This also seems reasonable because of the influence of external rules on Brazilian firms with substantial foreign ownership, such as through dual listing, especially the Sarbanes-Oxley Act. Works such as Peçanha (2007) and Camazano \& Arima (2008) provide evidence of this assertion.

\section{Methodological Aspects}

\subsection{Metrics to Detect Income Smoothing}

The method used here to determine the absence or presence of income smoothing is based on the coefficient of variation model proposed by Eckel (1981) and used later by Booth et al. (1996), Michelson et al. (1995; 2001), Bin et al. 
(2000) and Bao \& Bao (2004). These works show that if net income is related to sales by a linear function, variable unit costs remain constant over time, fixed costs do not decrease and gross revenue cannot be smoothed out, then the coefficient of variation of sales is smaller than the variation coefficient of net income. If this does not happen, Eckel (1981) showed that the company is artificially smoothing its income.

\section{$C V \Delta \%$ NetIncome $\leq C V \Delta \%$ Sales $\Rightarrow$ Smoothing}

where:

$\Delta \%$ Net Income $=$ Annual change in net income

$\Delta \%$ Sales $=$ Annual change in sales revenue;

Based on this logic, many relevant works have been published in the last 20 years, such as those of Albrecht \& Richardson (1990), Ashari et al. (1994), Booth et al. (1996), Michelson et al. (1995; 2001), Bin et al. (2000) and Bao \& Bao (2004). These authors all have calculated smoothing as an index of the fraction between the coefficients of variation $(\mathrm{CV})$ :

$$
I A_{1}=\frac{C V \Delta \% \text { NetIncome }}{C V \Delta \% \text { Sales }}
$$

Based on this, it is assumed that an index lower than 1 in absolute value indicates the presence of income smoothing because the coefficient of variation of net income is smaller than that of sales. Eckel (1981) demonstrated that this situation is a result of income smoothing by managers. We modified the model used in this study by using a smoothing index between 0.90 and 1.10 as the "gray area". This procedure is necessary to reduce the classification error, in accordance with the methodology of Chalayer (2004).

$$
\begin{gathered}
0.9 \leq\left\lfloor\left|\frac{C V \Delta \% \text { NetIncome }}{C V \Delta \% \text { Sales }}\right|\right\rfloor \leq 1.10 \\
\text { Smoothing } \leq \mid \text { Gray Area } \mid \leq \text { Non Smoothing }
\end{gathered}
$$

In this study we use a selection criterion between smoothers and nonsmoothers based on the smoothing index. The result of this smoothing index provides the basis to test the hypothesis that management is motivated to lower the variability of results and cash flow, all with the objective of reducing the firm's 
perceived risk.

\subsection{Database}

To analyze the relationship of income smoothing, ownership and control structure, level of corporate governance and origin of capital, we used a sample of nonfinancial companies with shares listed on the São Paulo Stock Exchange (Bovespa) at the end of 2007. There were around 500 such companies on that date, but we only used 266, mainly because of the absence of sufficient data to measure Eckel's smoothing index for many of these firms.

With respect to the time horizon, barring any structural shifts it is better to use a longer period of analysis. Our sample covers a period of ten years (19982007). However, to measure the ownership structure, we use a scale of one year, 2007. We obtained the data on capital structure and origin of capital from the reports published annually by the Brazilian Securities Commission (Comissão de Valores Mobiliários - CVM), and the information on corporate governance from the São Paulo Stock Exchange (Bovespa). Finally, we obtained the data to calculate the income smoothing index from the Economática database.

\subsection{Research Variables}

To analyze the hypotheses formulated, we defined some variables and analyzed them statistically. Following the works of Ribeiro et al. (2006) and Okimura et al. (2004), among others, we use the following variables of ownership and control structure:

(a) participation of the main stockholder in the total capital - the percentage of common and preferred shares detained by the controlling shareholder divided by the total common and preferred shares issued by the firm, representing the concentration of voting power and ownership (Structural Index 1 - STI1);

(b) participation of the main shareholder in the voting capital - the percentage of voting (common) shares divided by the total voting shares issued by the firm, representing the concentration of voting power (Structural Index 2 - STI2).

We calculated these indexes in decimal form from the information obtained from the websites of the CVM and Bovespa and used them as explanatory variables of income smoothing.

As mentioned above, we use the smoothing index proposed by Eckel (1981) and applied by various other authors, such as Booth et al. (1996) and Bin et al. (2000), among others. To calculate this index we used the following variables: 
(a) coefficient of variation of earnings (CVE); and (b) coefficient of variation of sales (CVS). According to Eckel (1981), income smoothing is a natural process, but when the sales revenue results are changed less than the earnings results, this indicates the process is intentional. This is the reason for using naturally related variables (profits and sales revenues) to identify the occurrence of income smoothing. According to this metric, when the coefficient of variation of earnings is lower than that of sales, this indicates income smoothing is an intentional process. When the contrary is true, the process is natural.

The smoothing index developed by Eckel (ESI) is the quotient of these two indexes. A value smaller than one indicates a firm is smoothing its income and a value greater than one indicates it is not. Also, the nearer the index is to zero, the more intensely the smoothing is.

From the data on companies with shares traded on the Bovespa and the information contained in the Economática database, we calculated the above two variables - CVE and CVS - and thus the smoothing index, calculated as an absolute value, to capture the effect of the explanatory variables of the model on the degree of income smoothing.

Our level of governance indicator is based on the work of Martinez \& Ramos (2006). They investigated whether listed Brazilian firms with more stringent corporate governance mechanisms are less likely to manage their earnings. As in their work, we use dummy variables to indicate the presence or absence of enhanced corporate governance mechanisms and the degree of governance, according to two methods: (1) a general dummy variable (Gr), which takes on the value of 0 for companies not following any enhanced governance requirement, and 1 for firms that do; and (2) a set of three dummies ( ) according to the three levels of enhanced corporate governance required for listing in three special segments of the Bovespa, Level 1, Level 2 and Novo Mercado ("New Market"), the most stringent: (a) if the company's shares are traded in the Level 1 segment and otherwise; (b) if the company's shares are traded in the Level 2 segment and otherwise; (c) if the company's shares are traded in the Novo Mercado segment and otherwise.

On the matter of origin of capital, we follow the study of Okimura et al. (2004). They stated that the origin of capital has an important influence on various policies of firms. Our objective here is not to study the type of controlling shareholder variable as a whole. We only examine two types of shareholders: foreign and domestic. It is important to mention that the foreign shareholder variable also involves those with securities traded abroad (ADRs), because those firms, although national, are in one form of another subject to the dictates of foreign legislation (such as SOX), as mentioned previously.

The origin of capital has an important influence on many facets of corpo- 
rate behavior, as mentioned earlier, due to the influence this can have on external rules and other factors, but these mechanism are not our focus here. We are only interested in assessing whether the origin of capital can explain a greater or lesser propensity to smooth income. Like for the corporate governance indicators, we use a dummy variable here: (a) for firms whose origin of capital is national, the value is 0 ; and (b) for firms with foreign capital or with securities traded abroad (ADRs) the value is 1 . As an alternative, we adopted the classification by which for companies without foreign capital, the value is 0 and for those with the presence of foreign capital it is 1 .

\subsection{Econometric Models}

The authors of the studies on the variables analyzed in this paper used various statistical techniques. Our findings here are based on a multiple regression model to explain a single variable, income smoothing, based on others that measure the ownership and control structure, level of corporate governance and origin of capital.

First we applied general equations to investigate the relationship of the explanatory variables with the smoothing index. Then we estimated specific equations to examine the hypotheses defined. We used the ANCOVA model (analysis of covariance model), in which the dependent variable is quantitative and the explanatory variables are both qualitative and quantitative, the latter of which are the control variables, called covariables. In this model the intercept is called a reference category and represents the average value of the set of the categories not designated with a dummy. In turn, the parameters are treated as differential intercept coefficients. In this form, the general equation for analyzing the total sample can be defined by:

$$
Y=\hat{\beta}_{0}+\hat{\beta}_{1} X_{1}+\hat{\beta}_{2} X_{2}+\hat{\beta}_{3} X_{3}+\hat{\mathcal{u}}
$$

In Equation (1), $\mathrm{Y}$ is the dependent variable, represented in this work by income smoothing. represents the model's intercept, and, and represent the coefficients referring to the independent or explanatory variables, represented by $x 1$ (ownership and control structure), x2 (origin of capital) and x3 (level of corporate governance). Finally, $\mathrm{u}$ is the standard error. Substituting the variables defined previously in Equation (1) results in eight equations to be estimated:

$$
E S I=\hat{\beta}_{0}+\hat{\beta}_{1} S T I 1+\hat{\beta}_{2} O C+\hat{\beta}_{3} G r+\hat{u}
$$




$$
\begin{aligned}
& E S I=\hat{\beta}_{0}+\hat{\beta}_{1} S T I 2+\hat{\beta}_{2} O C+\hat{\beta}_{3} G r+\hat{u} \\
& E S I=\hat{\beta}_{0}+\hat{\beta}_{1} S T I 1+\hat{\beta}_{2} P F C+\hat{\beta}_{3} G r+\hat{u} \\
& E S I=\hat{\beta}_{0}+\hat{\beta}_{1} S T I 2+\hat{\beta}_{2} P F C+\hat{\beta}_{3} G r+\hat{u} \\
& E S I=\hat{\beta}_{0}+\hat{\beta}_{1} S T I 1+\hat{\beta}_{2} O C+\hat{\beta}_{3} G_{1}+\hat{\beta}_{4} G_{2}+\hat{\beta}_{5} G_{3}+\hat{u} \\
& E S I=\hat{\beta}_{0}+\hat{\beta}_{1} S T I 2+\hat{\beta}_{2} O C+\hat{\beta}_{3} G_{1}+\hat{\beta}_{4} G_{2}+\hat{\beta}_{5} G_{3}+\hat{u} \\
& E S I=\hat{\beta}_{0}+\hat{\beta}_{1} S T I 1+\hat{\beta}_{2} P F C+\hat{\beta}_{3} G_{1}+\hat{\beta}_{4} G_{2}+\hat{\beta}_{5} G_{3}+\hat{u} \\
& E S I=\hat{\beta}_{0}+\hat{\beta}_{1} S T I 2+\hat{\beta}_{2} P F C+\hat{\beta}_{3} G_{1}+\hat{\beta}_{4} G_{2}+\hat{\beta}_{5} G_{3}+\hat{u}
\end{aligned}
$$

In these equations, ESI is Eckel's smoothing index; STI1 is the index of structure 1; STI2 is the index of structure 2; OC is the variable for origin of capital; PFC represents the presence of foreign capital, through issuance of ADRs; Gr indicates the firm adopts some degree of enhanced governance; and G1, G2 and G3 represent the different levels of enhanced governance, as discussed previously.

The objective of the above setup is to investigate whether there are robust and significant relations between the dependent variables and the various independent variables.

\section{Analysis of the Results}

From the initial sample of 266 firms (observations), we excluded 12 outliers, so the final sample consisted of 254 observations. The descriptive statistics of the quantitative variables are summarized in Table 1. 
Table 1. Descriptive statistics of the quantitative variables

\begin{tabular}{|l|l|l|l|}
\hline & ESI & STI1 & STI2 \\
\hline Mean & 2.109 & 0.54 & 0.698 \\
\hline Standard error & 0.15 & 0.016 & 0.014 \\
\hline Median & 1.381 & 0.534 & 0.681 \\
\hline Standard deviation & 2.398 & 0.25 & 0.229 \\
\hline Kurtosis & 9.748 & -0.846 & -0.17 \\
\hline Asymmetry & 2.863 & 0.105 & -0.521 \\
\hline Interval & 14.803 & 0.973 & 0.97 \\
\hline Minimum & 0.017 & 0.027 & 0.03 \\
\hline Maximum & 14.821 & 1 & 1 \\
\hline
\end{tabular}

Fonte: Dados da pesquisa

The average value of Eckel's smoothing index for the sample selected is 2.1 , with a range of 0.017 to 14.821 and a standard error of 0.15 . The distribution is asymmetric and leptokurtic.

The index for structure 1 (STI1), which represents the proportion between the main shareholder's equity stake and all the shares issued by the firm, has an average of 0.54, while the index for structure 2 (STI2), which represents the proportion between the main shareholder's voting shares and all the voting shares issued by the firm, has an average of 0.698 . The most common value for structure 1 is 0.545 while for structure 2 it is 1 . STI1 varies from 0.027 to 1 with a standard error of 0.016 , while STI2 ranges from 0.03 and 1 with a standard error of 0.014 . These figures confirm that ownership and control are very concentrated in Brazilian public companies, meaning that agency conflicts generally involve majority versus minority shareholders.

For purposes of analysis, we tested the indexes by substitution. The inclusion of two variables simultaneously in the estimation would result in high multicollinearity between the variables, which would be problematic because the standard errors are small and some regressions to test the model are composed of a small number of observations. Table 2 shows the frequency of the model's qualitative variables: 
Table 2. Descriptive statistics of the qualitative variables.

\begin{tabular}{|l|l|l|l|l|l|l|l|}
\hline Variable & Label & $\mathrm{Fi}$ & $\mathrm{Fi} \%$ & Variable & Label & Fi & Fi\% \\
\hline \multirow{3}{*}{ G1 } & $\begin{array}{l}\text { Other levels or } \\
\text { absence }\end{array}$ & 226 & 89 & Gr & $\begin{array}{l}\text { N o e n h a n c e d } \\
\text { governance }\end{array}$ & 188 & 74 \\
\cline { 2 - 8 } & Level 1 listing & 28 & 11 & & $\begin{array}{l}\text { Somelevel of enhanced } \\
\text { governance }\end{array}$ & 66 & 26 \\
\hline \multirow{2}{*}{ G2 } & Total & 254 & 100 & & Total & 254 & 100 \\
\hline & $\begin{array}{l}\text { Other levels or } \\
\text { absence }\end{array}$ & 246 & 96,9 & OC & National & 233 & 91.7 \\
\cline { 2 - 9 } & Level 2 listing & 8 & 3,1 & & Foreign & 21 & 8.3 \\
\cline { 2 - 8 } & Total & 254 & 100 & & Total & 254 & 100 \\
\hline \multirow{2}{*}{ G3 } & $\begin{array}{l}\text { Other levels or } \\
\text { absence }\end{array}$ & 224 & 88.2 & PFC & No & 175 & 68.9 \\
\cline { 2 - 8 } & $\begin{array}{l}\text { Novo Mercado } \\
\text { listing }\end{array}$ & 30 & 11.8 & & Yes & 79 & 31.1 \\
\hline & Total & 254 & 100 & & Total & 254 & 100 \\
\hline
\end{tabular}

Fonte: Dados da pesquisa

As pointed out before, we measure enhanced corporate governance in two forms, one considering the three different levels required for listing in special segments of the Bovespa and the other just considering whether or not the firm is listed in one of these categories. When measured by the first criterion, there are 28 observations for Level 1, 8 for Level 2 and 30 for the Novo Mercado listing segment, and thus 188 observations without any enhanced governance - whose results are captured by the intercept of the ANCOVA model. For the origin of capital, $91.7 \%$ of the firms have only national capital while $8.3 \%$ have foreign capital according to our classification scheme. Thus, the $\mathrm{OC}$ variable is present in Equations (2), (3), (6) and (7), and is replaced in the others by the foreign capital (PFC) variable. In $69 \%$ of the sample there is no presence of foreign capital, while in $31 \%$ of the firms there is.

To assess the relationship between ownership and control structure (measured both by the share of total equity held by the main shareholder and the share of voting capital held by that shareholder) on the smoothing index, as well as the influence of different corporate governance levels and origin of capital on this index, we analyzed the eight equations ( 2 to 9 ) by the ANCOVA model, using ordinary least squares (OLS). The results are shown in Table 3.

Of these eight estimations, the coefficients in only two of them do not indicate a joint influence on the dependent variable, as indicated by the F-statistic in Equations (6) and (8). According to the others, the null hypothesis is rejected that there is no joint influence of the respective independent variables on Eckel's smoothing index. Equations (3) and (5) are those that indicate the greatest joint 
influence on the dependent variable, according to the F-statistic. The $\mathrm{R}^{2}$ values are very low, but this is common in estimations with the ANCOVA model. The lowest values are in Equations (2), (4), (6) and (8). The significance of the variables OC and PFC is rejected in all the equations, and G2 also does not show any significant influence in the equations where it is included at the 0.05 level. With respect to the ownership structure indexes (STI1 and STI2), although they are both statistically valid, the coefficient of STI2 is more significant than that of STI1. There is a negative relationship between both of these and income smoothing, indicating that the greater the ownership and control structures is, the lower the smoothing index, meaning the greater the propensity to smooth.

We discarded Equations (6) and (8) because of their limited explanatory power, and then used the Akaike and Schwartz information criteria along with $\mathrm{R}^{2}$ and the F-statistic to establish that the models described by Equations (3) and (5) present more robust results. We thus selected them for analysis of the relations between the variables. According to the White test it was possible to reject the presence of heteroskedasticity in both the estimations, and the Ramsey RESET test indicated the validity of the functional form.

Table 3. Estimation of the coefficients of the general equations

\begin{tabular}{|l|l|l|l|l|l|l|l|l|}
\hline & \multicolumn{7}{|c|}{ Equation } \\
\hline Variable & 2 & 3 & 4 & 5 & 6 & 7 & 8 & 9 \\
\hline C & 2.941 & 3.395 & 2.966 & 3.476 & 2.967 & 3.425 & 2.997 & 3.501 \\
\hline & $(0.000)$ & $(0.000)$ & $(0.000)$ & $(0.000)$ & $(0.000)$ & $(0.000)$ & $(0.000)$ & $(0.000)$ \\
\hline STI1 & -1.079 & & -1.078 & & -1.122 & & -1.124 & \\
\hline & $(0.080)$ & nn & $(0.079)$ & & $(0.074)$ & & $(0.073)$ & \\
\hline STI2 & & -1.479 & & -1.526 & & -1.524 & & -1.564 \\
\hline & & $(0.026)$ & & $(0.022)$ & & $(0.025)$ & & $(0.022)$ \\
\hline OC & -0.065 & -0.152 & & & -0.085 & -0.130 & & \\
\hline & $(0.904)$ & $(0.778)$ & & & $(0.877)$ & $(0.812)$ & & \\
\hline PFC & & & -0.114 & -0.216 & & & -0.128 & -0.205 \\
\hline & & & $(0.727)$ & $(0.508)$ & & & $(0.697)$ & $(0.532)$ \\
\hline Gr & -0.936 & -0.928 & -0.921 & -0.904 & & & & \\
\hline & $(0.008)$ & $(0.007)$ & $(0.010)$ & $(0.009)$ & & & & \\
\hline G1 & & & & & -1.045 & -0.814 & -1.036 & -0.800 \\
\hline & & & & & $(0.039)$ & $(0.092)$ & $(0.040)$ & $(0.097)$ \\
\hline G2 & & & & & -1.047 & -0.910 & -1.038 & -0.896 \\
\hline & & & & & $(0.228)$ & $(0.289)$ & $(0.231)$ & $(0.296)$ \\
\hline G3 & & & & & -0.816 & -1.050 & -0.791 & -1.015 \\
\hline & & & & & $(0.084)$ & $(0.031)$ & $(0.098)$ & $(0.038)$ \\
\hline R 2 & 0.034 & 0.041 & 0.034 & 0.042 & 0.034 & 0.041 & 0.035 & 0.043 \\
\hline F & 2.898 & 3.554 & 2.935 & 3.679 & 1.755 & 2.144 & 1.781 & 2.214 \\
\hline \hline
\end{tabular}




\begin{tabular}{|l|l|l|l|l|l|l|l|l|}
\hline & $(0.036)$ & $(0.015)$ & $(0.034)$ & $(0.013)$ & $(0.123)$ & $(0.061)$ & $(0.117)$ & $(0.054)$ \\
\hline AIC & 4.580 & 4.573 & 4.580 & 4.571 & 4.595 & 4.588 & 4.595 & 4.587 \\
\hline SIC & 4.636 & 4.628 & 4.636 & 4.627 & 4.679 & 4.671 & 4.678 & 4.670 \\
\hline
\end{tabular}

Remark: P-value in parentheses.

Fonte: Dados da pesquisa Fonte: Dados da pesquisa

In ANCOVA models the intercept shows the average result of the categories of the dummies that do not assume a value of 1 . This intercept, , is called the reference category. In Equation (3) the reference category is composed of companies with national capital that do not have any enhanced corporate governance. This equation shows that when there is no special corporate governance policy and the origin of capital is national, Eckel's index is on average 3.395. Under similar governance, when there is foreign capital (through ADRs), the index is 0.152 , lower than the reference variable of 3.243 . However, this value is not reliable, because is not significant. The smoothing index (ESI) when there is some measure of higher corporate governance is 2.467 , because its coefficient indicates the ESI is 0.928 lower than the reference category. The equation also indicates that when the concentration index rises 0.1 , the smoothing index declines by about 0.148 .

The reference category of Equation (5) encompasses firms that do not have any special governance and have no participation of foreign capital through ADRs. The average ESI value for this category is 3.476. Since the coefficients of the ANCOVA model represent differences in relation to the reference category, the value of the smoothing index with the presence of foreign capital is 3.26. The model's control variable - the quantitative variable - indicates that an elevation of 0.1 in STI2 reduces the ESI by 0.153 .

Both equations evidence that the greater the ownership concentration is, as measured by the share of the voting capital held by the largest shareholder, the greater a firm's propensity to smooth income.

Hypothesis affirms that income smoothing occurs more intensely in firms where there is a clear separation between ownership and control. The previous estimations suggest that this hypothesis is not valid, given the negative relation between the ownership concentration indexes and the income smoothing index. The significant and negative relationship, as previously analyzed, indicates that the greater the ownership concentration is, the more intense smoothing will be. By dividing the sample into two blocks, one of firms with concentration indexes greater than or equal to $50 \%$ and the other of firms with indexes lower than $50 \%$, it can be seen that the smoothing index is greater in the former group, as shown in Table 4. 
Table 4. Differences in the average of Eckel's index

\begin{tabular}{|l|l|l|l|l|l|}
\hline Sample & Average of the ESI & $\mathrm{n}$ & Sample & Average of the ESI & $\mathrm{n}$ \\
\hline STI1 $\geq 0,5$ & 2.025 & 148 & STI1 $<0.5$ & 2.227 & 106 \\
\hline STI2 $\geq 0,5$ & 2.048 & 216 & STI2 $<0.5$ & 2.456 & 38 \\
& & & & & \\
\hline
\end{tabular}

Fonte: Dados da pesquisa

When the STI1 indicates concentrated ownership, the average ESI is 2.025, while when it is less concentrated the ESI is 2.227. This result holds when for the STI2, meaning that firms tend to smooth less when ownership is less concentrated. To corroborate this finding, we performed ANCOVA estimations for different samples. Excluding the variables $\mathrm{OC}$ and $\mathrm{PFC}$, which are not significant, Equations (3) and (5) take on the following forms to test the first hypothesis:

$$
\begin{aligned}
& E S I=\hat{\beta}_{0}+\hat{\beta}_{1} S T I 1+\hat{\beta}_{2} G r+\hat{u} \\
& E S I=\hat{\beta}_{0}+\hat{\beta}_{1} S T I 2+\hat{\beta}_{2} G r+\hat{u}
\end{aligned}
$$

Equation (10) involves the samples with STI1 $\geq 0.5$ and with STI1 $<0.5$, and Equation (11) involves the samples with STI2 $\geq 0.5$ and with STI2 $<0.5$. Estimation by OLS produced the results shown in Table 5 .

\begin{tabular}{|c|c|c|c|c|}
\hline & \multicolumn{4}{|c|}{ Equation } \\
\hline & \multicolumn{2}{|c|}{10} & \multicolumn{2}{|c|}{11} \\
\hline & \multicolumn{4}{|c|}{ Sample } \\
\hline Variable & STI1 $\geq 0,5$ & STI1 $<0.5$ & $\mathrm{STI} 2 \geq 0,5$ & STI $2<0.5$ \\
\hline \multirow[t]{2}{*}{$\mathrm{C}$} & 3.464 & 2.944 & 3.599 & 3.734 \\
\hline & $(0.000)$ & $(0.000)$ & $(0.000)$ & $(0.002)$ \\
\hline \multirow[t]{2}{*}{ STI1 } & -1.745 & -1.320 & & \\
\hline & $(0.171)$ & $(0.520)$ & & \\
\hline \multirow[t]{2}{*}{ STI2 } & & & -1.709 & -3.305 \\
\hline & & & $(0.076)$ & $(0.289)$ \\
\hline \multirow[t]{2}{*}{$\mathrm{Gr}$} & -0.990 & -0.925 & -0.986 & -0.656 \\
\hline & $(0.054)$ & $(0.067)$ & $(0.009)$ & $(0.485)$ \\
\hline $\mathrm{R}^{2}$ & 0.029 & 0.038 & 0.037 & 0.052 \\
\hline \multirow[t]{2}{*}{$\mathrm{F}$} & 2.201 & 2.059 & 4.139 & 0.952 \\
\hline & $(0.114)$ & $(0.133)$ & $(0.017)$ & $(0.396)$ \\
\hline
\end{tabular}

Table 5. Results of the estimation of Equations (10) and (11) for different samples

Remark: P-value in parentheses.

Fonte: Dados da pesquisa 
For the samples with ownership and control concentration measured by STI1, there was no significant influence on the dependent variable ESI. However, for the STI2 structure index, of the sample with the more concentrated ownership is significant while it is not for firms with less concentrated ownership. In other words, when the ownership is more concentrated, the impact on the ESI is significant. This does not occur for firms with less concentrated ownership. In this case, there is no significant relationship between the structure index and the income smoothing one. Besides this, the regression indicates that the relationship between the concentration and smoothing is negative, meaning to say that the more concentrated the ownership is, the more firms engage in income smoothing. Therefore, Hypothesis 1 is rejected.

Hypothesis 2 states that the effect of the ownership and control concentration on income smoothing is less pronounced for firms that have higher levels of corporate governance. To test this empirically, we divided the sample according to the governance level and then estimated by a simple linear regression the effect of the ownership structure on smoothing. This enabled us to compare the significance of the independent variable for the different levels of governance, by OLS, with the following equations:

$$
\begin{aligned}
& E S I=\hat{\beta}_{0}+\hat{\beta}_{1} S T I 1+\hat{u} \\
& E S I=\hat{\beta}_{0}+\hat{\beta}_{1} S T I 2+\hat{u}
\end{aligned}
$$

We applied both equations to the four samples of firms with different levels of governance. These samples have the following values for the dummy variable $:(1)=1$ for firms listed for trading in the Level 1 segment of the Bovespa, and 0 otherwise; (2) $=1$ for firms listed in the Level 2 segment, and 0 otherwise; (3) $=1$ for firms listed in the Novo Mercado trading segment, and 0 otherwise; and (4) $=1$ for firms listed in any of these trading segments, and 0 for those not subject to any enhanced corporate governance requirement. The results are shown in Table 6. 
Table 6. Results of estimating Equations (12) and (13) for different corporate governance levels

\begin{tabular}{|l|l|l|l|l|l|l|l|l|}
\hline & \multicolumn{9}{|c|}{ Sample } \\
\hline Variable & \multicolumn{2}{|c|}{ G1=1 } & \multicolumn{2}{c|}{ G2=1 } & \multicolumn{2}{c|}{ G3=1 } & \multicolumn{2}{c|}{ Gr=0 } \\
\hline \multirow{2}{*}{ C } & 1.827 & 1.489 & 1.322 & 0.842 & 2.359 & 2.359 & 2.982 & 3.640 \\
\cline { 2 - 10 } & $(0.002)$ & $(0.952)$ & $(0.122)$ & $(0.475)$ & $(0.004)$ & $(0.004)$ & $(0.000)$ & $(0.000)$ \\
\hline \multirow{2}{*}{ STI1 } & -0.857 & & 0.292 & & -1.534 & & -1.159 & \\
\cline { 2 - 10 } & $(0.538)$ & & $(0.860)$ & & $(0.269)$ & & $(0.122)$ & \\
\hline \multirow{2}{*}{ STI2 } & & 0.055 & & 0.869 & & -1.534 & & -1.834 \\
\cline { 2 - 9 } & & $(0.036)$ & & $(0.590)$ & & $(0.269)$ & & $(0.031)$ \\
\hline R ${ }^{2}$ & 0.015 & 0.001 & 0.006 & 0.051 & 0.043 & 0.043 & 0.013 & 0.025 \\
\hline
\end{tabular}

Remark: P-value in parentheses.

Fonte: Dados da pesquisa

Analysis of the estimations from the simple linear regressions of Equations (12) and (13) shows that no coefficient of the STI1 variable was significant. This indicates there is no cause and effect relationship between the variables for the sample cross section selected. The first sample, where $=1$, has 28 observations, while the other three have 8, 30 and 188 observations, respectively. The limited number of observations for the second cross section, $=1$, contributed to the small $\mathrm{R}^{2}$ value for this sample. The results for both STI1 and STI2 indicate that when there is some increased level of corporate governance, the relations between the structural index and the smoothing index are not significant. However, when there is no enhanced governance, the P-values of increase and are highly significant for STI2 as the independent variable. This shows that not only is smoothing greater without increased governance, but also that when governance is more stringent, the relationship between the structure index and the smoothing index remains strong. Therefore, it is not possible to reject the second hypothesis.

Because the results of Equations (3) and (5) were more significant, we used them to estimate the expected value of ESI to test the third hypothesis. To do this, we formed a sub-sample considering only the ownership and control structure and income smoothing, According to this scheme, Equations (3) and (5) estimate the ESI considering STI2 0.5 and ESI $<1$. To observe the conditional means, we considered four sample cross-sections: Sample $1-$ when STI2 0.5, $\mathrm{ESI}<1$ and $\mathrm{OC}=0$; Sample $2-$ when STI2 0.5, ESI $<1$ and $\mathrm{OC}=1$; Sample 3 - when STI2 0.5, ESI $<1$ and PFC $=0$; and Sample $4-$ when STI2 0.5, ESI $<1$ and $\mathrm{PFC}=1$. 
Table 7. Mean of the ESI of the chosen samples

\begin{tabular}{|c|c|c|c|c|}
\hline Sample & $\mathrm{n}$ & Mean of the ESI & Minimum & Maximum \\
\hline 1 & 67 & 0.485 & 0.02 & 0.99 \\
\hline 2 & 6 & 0.671 & 0.07 & 0.99 \\
\hline 3 & 52 & 0.473 & 0.04 & 0.99 \\
\hline 4 & 21 & 0.567 & 0.02 & 0.99 \\
\hline
\end{tabular}

Fonte: Dados da pesquisa

The means of the ESI in Samples 1 and 3 suggest that when there is no foreign capital, income smoothing is greater, because the ESI assumes lower values than in Samples 2 and 4, in which the firms have foreign capital. We verified the validity of this hypothesis with ANVOVA analysis. With STI2 0.5 and ESI $<1$, the estimation of Equations (3) and (5) produced the results shown in Table 8.

Table 8. Estimation of the coefficients of Equations (3) and (5)

\begin{tabular}{|c|c|c|c|c|c|c|c|c|c|}
\hline \multirow[t]{2}{*}{ Equation } & \multicolumn{9}{|c|}{ Variable } \\
\hline & $\mathrm{C}$ & STI2 & $\mathrm{OC}$ & PFC & $\mathrm{Gr}$ & $\mathrm{R}^{2}$ & $\mathrm{~F}$ & $\mathrm{AIC}$ & SIC \\
\hline \multirow[t]{2}{*}{ (3) } & 0.117 & 0.413 & 0.086 & & 0.214 & 0.153 & 4.156 & 0.193 & 0.318 \\
\hline & $(0.458)$ & $(0.036)$ & $(0.460)$ & & $(0.005)$ & & $(0.009)$ & & \\
\hline \multirow[t]{2}{*}{ (5) } & 0.090 & 0.445 & & 0.033 & 0.214 & 0.149 & 4.022 & 0.198 & 0.323 \\
\hline & $(0.562)$ & $(0.020)$ & & $(0.649)$ & $(0.007)$ & & $(0.011)$ & & \\
\hline
\end{tabular}

Fonte: Dados da pesquisa

Both Equations (3) and (5) show a significant influence of the independent variables on the dependent variable, as can be seen from the P-value of the F-statistic. The value of $\mathrm{R}^{2}$ is satisfactory for both equations. Once again the variables STI2 and Gr have significant coefficients. The coefficients of OC and PFC are not significant in their respective equations. These results to not differ from the general estimations, but a particularity of this sample is the positive relation between STI2 and ESI. Given the characteristics of the sample, this result can be interpreted as indicating that for firms with concentrated ownership and control that smooth income, the greater the participation of the main shareholder is in the voting capital, the greater the smoothing index is, so the less the propensity is to smooth income. An increase of 0.1 in the participation of the main stockholder, ceteris paribus, raises the smoothing index by 0.04 . The value of $\mathrm{R}^{2}$, the F-statistic and the AIC and SIC values all indicate that Equation (3) as being the best adjusted and producing the most significant response. The equation corresponds to: 


$$
\mathrm{ESI}=0.117+0.413(\mathrm{STI} 2)+0.214(\mathrm{Gr})+0.086(\mathrm{OC})
$$

The coefficients obtained in the ANCOVA model indicate differences in relation to the intercept. The reference category in Equation (14) reveals the average smoothing index for firms without ADRs and no enhanced corporate governance. The value of indicates that for firms with ADRs, all else constant, the smoothing index is 0.086 higher that that of the reference category. Therefore, irrespective of whether Gr assumes a value of 0 or 1 , when there is foreign capital, the smoothing index is greater than it is for firms only listed on the Bovespa. In this form, the third hypothesis is not rejected.

\section{Conclusion}

The results of the covariance model, where the dependent variable is the smoothing index of Eckel, indicate there is a significant influence of the ownership and control structure on income smoothing. The estimations for all 254 observations show that the relationship between the variables is negative. In other words, when the ownership and control index rises, the smoothing index falls. Since this index suggests that smoothing takes place when it is lower than 1 and this smoothing is stronger as the index approaches zero, the negative relationship between the indexes indicates that the greater the ownership and control is, the more intensely firms smooth their earnings.

This result obtained for the full sample confirms the first hypothesis. However, when the sample is restricted only to companies that smooth income and have concentrated ownership, the relationship between the smoothing index and the concentration index becomes positive. For this specific sample, the greater the concentration of shares held by the main shareholder, the higher the smoothing index is, meaning the less the propensity to smooth.

The results of analysis of the means, simple linear regression and ANCOVA show that neither the second nor third hypotheses can be rejected. Therefore, (a) the effect of the ownership and control concentration on smoothing is lower for companies that have enhanced corporate governance; and (b) firms with concentrated ownership and control that smooth income do so less intensely when they have foreign capital.

The good response obtained by Equations (3) and (5) means they are workable alternatives to estimate Eckel's smoothing index. The results thus indicate that when corporate governance is measured by a single dummy variable, representing the absence or presence of some level of enhanced governance, the model's response is more robust. The same applies when ownership concentration 
is measured by the portion of the voting capital held by the main shareholder (rather than of the total capital). In contrast, the origin of capital variable, or its substitute, presence of foreign capital, was not significant in the analyses carried out.

The analysis here of the relationship between the ownership and control structure and income smoothing for Brazilian firms expands the knowledge of this relationship to a setting unlike the United States and Europe, examined by previous works. Due to the typically high concentration or shareholding in Brazil, agency problems more often involve conflicts between majority and minority shareholders rather than between shareholders and managers. As demonstrated here, the specific nature of the agency conflicts in Brazil creates different incentives to smooth income.

This study has many practical implications. Above all, it is important for regulators to consider the institutional peculiarities of the country before establishing accounting rules. In the Brazilian case, the concentrated ownership and control structure provides perverse incentives for managers to reduce the quality of accounting information by managing earnings.

Several extensions of this work can be suggested. One would be to test the variables used here on panel data, to examine the random and fixed effects. In general, there is a need for further research on the effects of these and other variables on the propensity of Brazilian firms so smooth their reported income.

\section{Referências}

Albrecht, W.D., \& Richardson, F.M. (1990). Income smoothing by economy sector. Journal of Business Finance and Accounting, 7(5), 713-730.

Amihud, Y., Kamin, J., \& Ronen, J. (1983). Managerial ownerism and risk. Journal of Banking and Finance, 7 (1), 189-196.

Ashari, N., Koh, H.C., Tan, S.L., \& Wong, W.H. (1994). Factors affecting income smoothing among listed companies in Singapore. Accounting and Business Research, 24(96), 291-301.

Bao, B. H., \& Bao D. H. (2004). Income smoothing, earnings quality and firm valuation. Journal of Business Finance and Accounting, 32(9), 1525-1557.

Babic, V. (2003). Corporate Governance Problems in Transition Economies. Winston-Salem: Wake Forest University (Social Science Research Seminar).

Beattie, V., Brown, S., Ewers, D., John, B., Manson, S., Thomas, D., \& Turner, M. (1994). Extraordinary items and income smoothing: A positive accounting 
approach. Journal of Business, Finance and Accounting, 21 (6), p. 791-811.

Berle, A., \& Means, G. (1932). The modern corporation and private property. Nova Iorque: McMillan.

Beidleman, R. (1973). Income Smoothing: The role of management. The Accounting Review, 98 (4), p. 653-667.

Bin, K Wan, \& Kamil, K (2000). Market perception of income smoothing practices: Malaysian evidence. Journal of Economics and Finance, 26 (2), 132-146.

Booth, G.G., Kallunki, J.P., \& Martikainen, T. (1996). Post-announcement drift and income smoothing: Finnish evidence. Journal of Business Finance and Accounting, 23(8), 1197-1211.

Camazano, M., \& Arima, C. (2008, September). Influência do Sarbanes-Oxley Act of 2002 - SOX sobre o Gerenciamento do Risco Operacional em Instituições Financeiras Brasileiras. Anais do Encontro Nacional da Associação Nacional de Pós-Graduação e Pesquisa em Administração, Rio de Janeiro, RJ, Brazil, 32.

Chalayer, S. (1994). Identification et motivations des pratiques de lissage dês résultats comptables des entreprises françaises cotées en Bourse. Doctoral Thesis, Université de Saint-Etienne, Saint-Etienne, France.

Eckel, N. (1981). The income smoothing hypothesis revisited. Abacus, 17(1), $28-40$.

Fontes, J. R., Filho. (2003, July). Estruturas de propriedade, governança corporativa e estratégia empresarial. Anais do Encontro de Estudos em Estratégia da Associação Nacional de Pós-Graduação e Pesquisa em Administração, Curitiba, PR, Brazil, 1.

Gordon, M. J, (1964). Postulates, Principles and Research in Accounting. The Accounting Review, 251-63.

Healy, M., \& Whahlen, M. (1999). A review of the earnings management literature and its implications for standard setting. Accounting Horizons, 13 (4), 365-383.

Jensen, C., \& Meckling, H. (1976). Theory of the firm: managerial behavior, agency costs and ownership structure. Journal of Financial Economics, 3 (4), 205-360.

Kamin, J., \& Ronen, J. (1978). The smoothing of income numbers: Some empirical evidence on systematic differences among management-controlled and owner- 
controlled firms. Accounting Organizations and Society, 3 (2), 141-157.

Koch, B. (1981). Income smoothing: An experiment. The Accounting Review, $56(3), 574-586$.

Martinez, A. L. (2001). Gerenciamento dos resultados contábeis: estudo empírico das companhias abertas brasileiras. Doctoral Thesis, Universidade de São Paulo, São Paulo, Brazil.

Martinez, A. L., \& Ramos, G. M. (2006). Governança Corporativa e Earnings Management. Revista Contemporânea de Contabilidade, 3 (2), 143-164.

McNichols, F. (2000). Research design issues in earnings management studies. Journal of Accounting and Public Policy, 3 (19), 313-345.

Michelson, S.E., Jordan-Wagner, J., \& Wootton, C.W. (1995). A market based analysis of income smoothing. Journal of Business Finance and Accounting, 22 (8), 1179-1193.

Michelson, S.E., Jordan-Wagner, J., \& Wootton, C.W. (1999). The relationship between the smoothing of reported income and risk-adjusted returns. Journal of Economics and Finance, 24(2), 141-159.

Michelson, S.E. Jordan-Wagner, J, \& Wooton, C.W. (2001). Accounting income smoothing and stockholder wealth. Journal of Applied Business Research, 10(3), 96-110.

Okimura, R., Silveira, A., \& Rocha, K. (2004). Estrutura de propriedade e desempenho corporativo no Brasil. Anais do Encontro Nacional da Associação Nacional de Pós-Graduação e Pesquisa em Administração, Curitiba, PR, Brazil, 28.

Paulo, E. (2007). Manipulação das informações contábeis: uma análise teórica e empírica sobre os modelos operacionais de detecção de gerenciamento de resultados. Doctoral Thesis, Universidade de São Paulo, São Paulo, Brazil.

Peçanha, M. (2007). Um estudo sobre a influência da Lei Sarbanes-Oxley no nível de transparência dos relatórios anuais - estudo de caso da Petrobrás. Master's Dissertation, Instituto Brasileiro de Mercados de Capitais, São Paulo, Brazil.

Rajgopal, S., M. Venkatachalam, \& J. Jiambalvo. (2002). Is Institutional Ownership Associated with Earnings Management and the Extent to which Stock Prices Reflect Future Earnings? Contemporary Accounting Research, 19 (1), 117-136.

Rapozo, F., Pagliarussi, M., \& Aquino, A. (2007, September). Estrutura de proprie- 
dade, custos de agência e desempenho: estudo de caso de um grupo empresarial familiar. Anais do Encontro Nacional da Associação Nacional de Pós-Graduação e Pesquisa em Administração, Rio de Janeiro, RJ, Brazil, 31.

Ribeiro, K., Dami, A., Rogers, P., \& Silva, W. (2006, October). Estrutura de propriedade no Brasil: evidências empíricas no grau de concentração acionária. Anais do Congresso USP de Contabilidade e Controladoria, São Paulo, SP, Brazil, 8.

Rogers, P., Ribeiro, K., \& Securato, J. (2006). Governança corporativa, mercado de capitais e crescimento econômico no Brasil. Anais do Encontro Nacional da Associação Nacional de Pós-Graduação e Pesquisa em Administração, Salvador, BA, Brazil, 30.

Ronen, J., \& Sadan, S. (1981). Smoothing Income Numbers: Objectives, means and implications. Massachusetts: Addison-Wesley Publishing Company.

Shleifer, A., \& Vishny, R. (1997). A Survey of Corporate Governance. Journal of Finance, 52 (2), 737-783.

Silveira, A. (2004). Governança corporativa e estrutura de propriedade: determinantes e relação com o desempenho das empresas no Brasil. Doctoral Thesis, Universidade de São Paulo, São Paulo, SP, Brazil.

Smith, D. (1976). The effect of the separation of ownership from control on accounting policy decisions. The Accounting Review, 51 (4), 707-723.

Tukamoto, Y. (2004). Contribuição ao estudo do gerenciamento de resultados: uma comparação entre as companhias abertas brasileiras emissoras de ADR's e não emissoras de ADR's. Master's Dissertation, Universidade de São Paulo, São Paulo, Brazil. 
